\title{
A Comparative Analysis of the Trade and Industrial Policies of Ukraine and China in the Context of the Obor Initiative
}

\author{
Tamara Ostashko (D) https://orcid.org/0000-0001-5550-5864 \\ Sc.D., Corresponding Member, National Agrarian Academy of Sciences of Ukraine \\ Principal Researcher, Institute for Economics and Forecasting, NAS of Ukraine \\ Kyiv, Ukraine, e-mail: tostashko@ukr.net
}

Volodymyr Olefir (iD) https://orcid.org/0000-0003-4180-3435

Ph.D., Senior Researcher, Institute for Economics and Forecasting, NAS of Ukraine Kyiv, Ukraine, e-mail: oksavol@ukr.net

Vitalii Venger (iD https://orcid.org/0000-0003-1018-0909

Sc.D., Leading Researcher, Institute for Economics and Forecasting, NAS of Ukraine Kyiv, Ukraine, e-mail: vengerv@ukr.net

\section{Olena Boiko (iD) https://orcid.org/0000-0002-6567-1679}

Ph.D., Leading Researcher, Institute for Economics and Forecasting, NAS of Ukraine Kyiv, Ukraine, e-mail: bhelena@ukr.net
Abstract
The world economy is evolving towards multipolar globalization, and China has be- come a new pole of economic development. Ukraine, like other countries, is looking for ways to cooperate with China in the field of trade and investment. China, for its part, offers a model of cooperation within the framework of the OBOR (One Belt, One Road) initiative. Along with Chinese investment in transport and logistics infrastruc- ture, OBOR aims to conclude FTAs with the countries participating in the initiative; thus, the article focuses on the issues of trade, and Ukraine's industrial and innovation policy in the context of the OBOR initiative. A comparative analysis of both coun- tries' trade and industrial policies was conducted to provide a basis for evaluation. The terms of trade between Ukraine and China are not symmetrical due to the difference in the scale of the economy and trade. Additionally, Ukraine's trade regime is relatively 
liberal, while the Chinese market is protected by higher tariff and non-tariff barriers. Furthermore, the current situation in mutual trade is asymmetric. Ukraine exports mainly raw materials to China, while exports from China to Ukraine are dominated by investment and consumer goods.

The import dependence of the Ukrainian economy, in general, is high without any noticeable signs of decline. In 2014-2018, the share of imports of goods and services in GDP in Ukraine averaged 54\% (for comparison, in China, this parameter was 19\%). In 2018, 55\% of Ukraine's negative balance in trade in goods was due to trade with China. China seeks to conclude FTAs under the OBOR initiative, but in the current context, the liberalization of trade regimes with China will result in Ukraine growing its raw material exports to China and increasing its dependence on Chinese imports. On the other hand, China's investment, production, research, and technological opportunities can become an important resource for Ukraine to modernize its economy. Promising areas of Chinese investment include high technology, in particular, aviation, shipbuilding, bioengineering, the development of new materials, and more. Ukraine is interested in China's experience in implementing a number of state programs in the field of innovation development of Chinese industrial enterprises. The support system for clusters, industrial parks, Free Economic Zones (FEZs), and technology parks can be recommended for introduction into Ukrainian legislation in the sphere of developing an innovation structure in Ukraine.

Keywords: One Belt One Road initiative, China, Ukraine, trade policy, FTA, industrial policy, innovation policy

JEL: F13, F21, O38, O57

\section{Introduction}

Multipolar globalization has become the main direction of world economic development. In the world market, several competing economic poles have evolved, which generate the largest flows of exports and imports of goods and services. At the same time, small economies are becoming more open and are grouped around economic poles into regional blocs. These processes require empirical research, theoretical understanding, and the development of rational trade policy. One of the modern economic poles is the People's Republic of China, and the current model of its regional cooperation is the One Belt, One Road (OBOR) initiative.

On the other hand, with China becoming the world's leading economy, many countries are looking for ways to cooperate profitably with China in trade and investment. China is proposing a model for such cooperation from its side as part of its OBOR initiative. Research on the prospects of EU participation in the OBOR initiative is being conducted in EU countries, in particular, in Poland (Bieliński, Markiewicz, and Oziewicz 2019, pp. 7-22; Choroś-Mrozowska 2019, pp. 39-53). Research in this field is also important for Ukraine, as there is still great potential for economic relations between Ukraine and China. In 2017, Ukraine and China signed a "road map" for the imple- 
mentation of the Great Silk Road Economic Belt initiative (North Line B of the OBOR initiative, Beijing - Russia - Germany - Northern Europe). However, this document has not yet given impulse to the development of trade between China and Ukraine, nor to Ukraine's involvement in Eurasian logistics for the transportation of goods between China and the EU, or to cooperation in the field of industrial production.

Due to the complication of trade relations with the Russian Federation, Ukraine's participation in the development of the Economic Belt of the Great Silk Road, in general, is quite problematic. Instead, progress is possible in the development of Ukraine's trade with China and the attraction of Chinese investment to Ukraine.

The purpose of the paper is to determine the prospects and ways for Ukraine to join the Chinese government's OBOR initiative in the field of bilateral trade and Chinese investment in Ukrainian industry. It should be mentioned that OBOR will consist not only of a network of ports, roads, railways, airports, power plants, oil and gas pipelines, and refineries, but also free trade areas. A boost to mutual trade would be possible if an FTA between Ukraine and China were established, but the liberalization of trade between Ukraine and China carries many risks in addition to potential benefits, as it could increase Ukraine's raw material exports and increase its dependence on Chinese imports. The development of mutual trade between Ukraine and China is already creating challenges for the domestic economy, given that more than half of the negative balance in Ukraine's trade in goods is caused by trade with China (55\% in 2018).

Despite the danger of the further deterioration of the trade balance, the Ukrainian side initiated the launch of consultations on the Ukrainian-Chinese Free Trade Agreement (FTA). A comparative analysis of Ukraine and China's trade policies is an essential step to assess the development potential of Ukrainian exports to China and the risks of increasing Ukraine's domestic market dependence on Chinese imports. This analysis will provide arguments to prove the research hypothesis that there is no evidence of the benefits of concluding an FTA with China, although it should be noted that Ukraine's refusal to launch FTA negotiations with China would not mean refusing to participate in the OBOR initiative itself. As import duties are relatively low in most commodity markets around the world, the main trade barriers are transport costs and non-tariff measures, which the OBOR initiative aims to overcome. In particular, according to the WTO, China has allocated 1 billion US dollars to this organization to implement Trade Facilitation Agreements (TFAs) for developing countries (WTO 2018a). In Ukraine, the TFA implementation process started in 2015, which will definitely contribute to the implementation of the OBOR initiative. In addition, even if Ukraine does not follow through with the negotiations on FTA with China, it will not create barriers to attracting Chinese investment to Ukraine. There is a great demand for foreign direct investment in Ukraine, including investment from East Asia. In our opinion, in the context of the OBOR initiative, the Chinese side will also benefit from investing in the Ukrainian economy given its proximity to the EU, developed transport infrastructure, and high transit potential. 
A comparative analysis of Ukraine and China's industrial policies makes it possible to identify existing opportunities and assess the prospects for attracting Chinese investment in Ukrainian industry. Currently, several agreements on the implementation of various sectoral innovation programs have been concluded, including a Joint Declaration on the Establishment and Development of Strategic Partnership Relations between Ukraine and China (2011), an Agreement between the Government of Ukraine and the Government of the People's Republic of China on Technical and Economic Cooperation (2015), a Strategic Cooperation Agreement between Motor Sich Joint-Stock Company, Ivchenko-Progress State Enterprise, and the Chinese Aviation Corporation AVIC International Holding Corporation (2013), and an Agreement on Cooperation in the Fields of Energy Efficiency, Energy Saving and Renewable Energy Sources between the State Agency for Energy Efficiency and Energy Saving of Ukraine and the Chinese Export Credit Corporation (SINOSURE 2013).

In accordance with the outlined problems and the purpose of the paper, the detailed research tasks are as follows: (1) to conduct an analysis of trade development and a comparative analysis of the trade policy of China and Ukraine and verify the research hypothesis that there is no evidence of the benefits of an FTA with China; (2) to conduct a comparative analysis of import substitution policy in Ukraine and China; (3) to identify the specifics of China and Ukraine's industrial policy and areas for attracting Chinese investment to Ukraine's industry; and (4) to compare innovation policy in China and Ukraine to develop recommendations for to stimulate modern forms of innovation infrastructure in Ukraine and promote Chinese investment in innovation activities.

\section{Methods and sources}

The study used methods of comparative analysis - to compare the trade, industrial, and innovation policies of Ukraine and China; system thinking - to identify and justify the priority areas for attracting Chinese investment in Ukrainian industry; to reveal risks and positive aspects of development, to define special features of innovation activity in China and Ukraine; methods of statistical analysis (time series, grouping, etc.) - to assess the level of import dependence of Ukraine and China, to estimate the basic indicators of innovation activity in both countries and in the study of bilateral trade flows.

Official data and information sources, academic and analytical papers were used for the research. The analysis of China's non-tariff regulation is based on China's trade policy reports prepared in 2018 by the WTO Secretariat (WTO 2018b) and the Government of China (WTO 2018c). Data from the UN Comtrade Database were used in the study of trade flows, while data from the World Bank and the State Statistics Service of Ukraine were used for the comparative analysis of the level of import dependence of Ukraine and China. Academic and analytical studies of China's strategy 
in negotiations on the FTA, and the consequences of trade liberalization with China for other countries, were used along with an empirical approach to verify the working hypothesis that there are no benefits for Ukraine from the FTA with China.

\section{China's trade policy and the question of the feasibility of a China-Ukraine FTA}

Between 2013 and 2018, Ukrainian exports of goods to China decreased by 19.3\%, while imports during the same period decreased by $3.7 \%$ (Figure 1). The decrease in Ukraine's trade with China could be explained by the economic crisis in Ukraine, which started in 2014. While imports of goods to Ukraine from China have almost recovered since the beginning of the crisis, exports are growing at a slow pace.

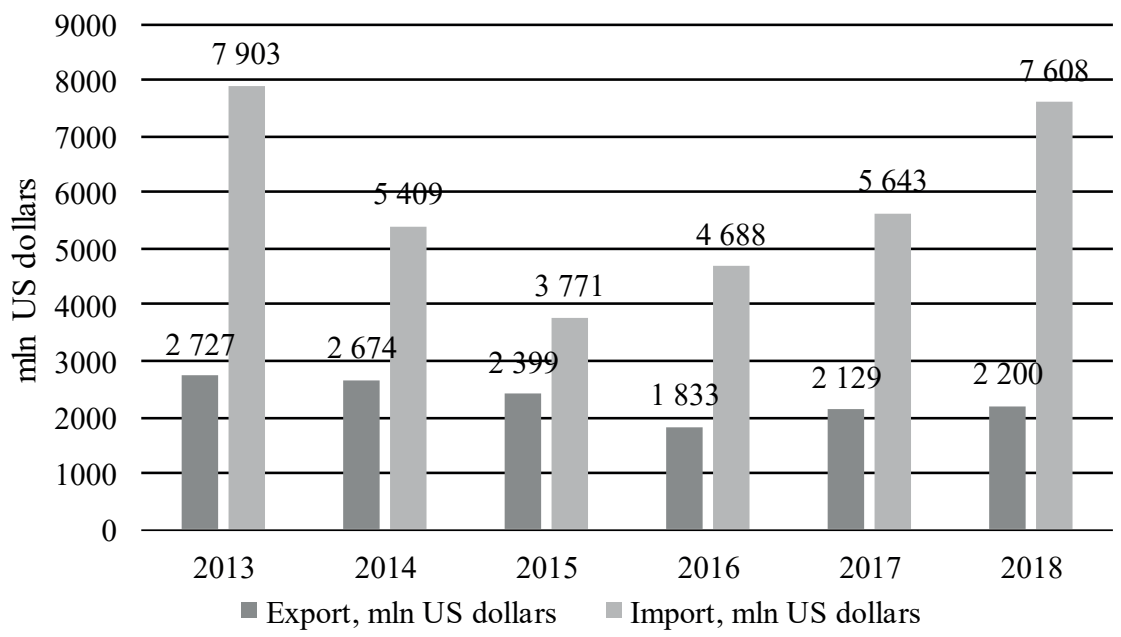

Figure 1. Ukraine's foreign trade in goods with China, 2013-2018, US dollars (millions) Source: UN Comtrade Data Base.

The structure of Ukrainian exports of goods to China is dominated by raw materials, namely, three commodity groups - metals, grains, and oils, which together account for $74.1 \%$ of Ukrainian commodity exports to China. Agricultural exports have the best prospects (Ostashko and Olefir 2019, pp. 124-152). The supply of food to China is one of the main benefits that China plans to gain from the OBOR initiative.

The terms of trade between Ukraine and China have not been symmetrical from the very beginning due to the difference in the scale of the economy and trade. In addition, Ukraine's economy is more open than China's. The average bound tariff (the level at which countries agreed to "bind" their tariffs according to the schedule of tariff reductions upon WTO accession) is $5.9 \%$ for Ukraine and $10 \%$ for China. This means 
that today, when both countries have already fulfilled their obligations to reduce tariffs, the level of tariff protection in China is much higher than in Ukraine. Therefore, it could be concluded that mutual liberalization of tariff regimes is beneficial for Ukraine; however, all benefits of China's tariff liberalization could be eliminated by special features of China's non-tariff customs regulation.

The state plays a key role in the procedures that must be undertaken while entering the Chinese market, so interstate trade agreements benefit launching and developing trade with China. All importers must register as foreign trade operators with the Ministry of Commerce of the People's Republic of China (MOFCOM) or its authorized bodies. China classifies imports into three categories: non-restricted imports, restricted imports, and prohibited imports.

It should be mentioned separately that China is not obliged to lift the ban on importing certain goods in the framework of WTO accession. Thus, the Protocol on China's Accession to the WTO (WTO 2001a) only mentions China's obligation to publish the list of all goods and technologies whose import or export is restricted or prohibited in a regular official publication (Section 8 (a) of the mentioned Protocol). The lifting of bans and the rejection of imposing of new bans on importing certain goods are also not mentioned in the Report of the Working Party on China's Accession to the WTO (Section 8 "Quantitative Restrictions on Imports Including Prohibitions and Quotas") (WTO 2001b, pp. 23-26).

In 2004, China passed a new Law on Foreign Trade (MOFCOM 2004) that significantly expands the list of goods that may be subjected to import restrictions and bans. Article 16 of this Law stipulates that the state may restrict or prohibit the import of certain goods and technologies in order to protect growth or stimulate the creation of a particular domestic industry, as well as restrict the import of agricultural goods. Therefore, prospects for the development of Ukrainian agricultural exports in the case of concluding an FTA with China are far from clear and will be constantly threatened by the introduction of bans by the Chinese government.

While the Chinese government is actively pursuing a policy of trade protectionism to protect its own producers and promote the development of certain industries, international experts believe that China is violating the commitments made in the framework of WTO accession (AEGIS EUROPE 2016). Such violations include, in particular, the adoption of the Plan for Innovative Development of High-Tech Industries, the so-called new strategic industries, and the non-fulfillment of obligations to implement international standards. China continues to develop its own unique national standards to protect its companies from international competition. This policy of China is called “innovation mercantilism” (Ezell and Atkinson 2015).

While evaluating the expediency of concluding an FTA with China, it is important to analyze the specifics of the FTA negotiations by the Chinese side. As of March 2019, China has signed and implemented 16 free trade agreements; these FTAs are more diverse than regional agreements signed by the EU or US. Thus, US regional agreements typically offer accelerated tariff elimination bilaterally in exchange for what 
is actually unilateral liberalization of services by the second party. EU agreements emphasize the harmonization of the institutional environment and market competition regulation. Unlike the US and the EU, Chinese agreements are based on diverse approaches to trade liberalization. China is adamant about opening up agricultural markets due to lobbying for its own producers and food security considerations. Its desire to maintain a high level of protection of food markets for food security reasons is considered the most serious obstacle to the progress of FTA negotiations with China. This actually eliminates the advantages of implementing an FTA between Ukraine and China because Ukraine's agricultural sector can become almost the only beneficiary of this FTA.

There are also problems related to translation, especially in periods of aggravation of the negotiation process and the tough position of the Chinese side in negotiations on services, investment, and public procurement agreements (Lingling 2013, pp. 672 696). The seriousness of translation problems in trade relations with China is also noted by researchers from the Foundation for Innovative Technologies and Innovations from the United States, who study China's fulfillment of its obligations to the WTO (Ezell and Atkinson 2015, p. 3). It was even suggested to increase funding for the translation of China's strategic documents, especially those related to the development plans of China's so-called seven strategic and new industries, because, despite its commitments, China does not provide timely notifications to the WTO. It is also noted that China still does not report all new or revised standards, technical regulations, or conformity assessment procedures, as required by WTO rules.

Therefore, in the case of negotiations on the FTA between China and Ukraine, their complex nature and the intransigence of the Chinese to open their agricultural markets should be considered. In addition, even if the Ukrainian side manages to improve its access to the Chinese agricultural market, there is a danger that these markets could be closed at any time because, as mentioned above, according to Article 16 of the Law on Foreign Trade of China, the importing of animal, plant, and fishery products may be restricted if circumstances so require.

Furthermore, in FTA negotiations with countries that export agricultural goods, the Chinese agree to establish tariff quotas on imports of agricultural products. In particular, tariff quotas on agricultural imports into China are set in the FTA with Australia and New Zealand. In FTAs with other countries, agricultural products are generally excluded from the liberalization regime; for example, in the FTA between China and Georgia (2018), durum wheat, soybeans, corn, sugar, and milk powder are excluded from the free trade regime (WTO 2018b, p. 35). Thus, the size of zero-tariff quotas for agricultural exports will be the core issue in the FTA negotiations between Ukraine and China.

Another feature of China's FTAs with agricultural exporters is that they contain a section on special agricultural safeguards. Such sections were included in the FTA with Australia (Article 2.14 of the Agreement) (MOFCOM 2015) and with New Zealand (Article 13 of the Agreement) (MOFCOM 2008). These sections allow China to impose 
an additional protective tariff on imports of agricultural products if the volume of imports or the price of imported goods threatens its domestic market. In particular, in the FTA with Australia, special agricultural safeguards protect China's beef and dairy markets, which are not subjected to tariff quotas. It is obvious that the symmetrical measures that the Ukrainian side can defend in the negotiations may be the introduction of a protective mechanism in certain markets for light industry goods.

\section{Comparative analysis of the domestic market protection policy and import substitution in China and Ukraine}

The policy of domestic market protection and import substitution should take into account the parameters of the national economy, its dynamics, and structure. Ukraine's economy today can be considered small and open, while China's economy is large and closed. Ukraine's economy has been stagnant for the past ten years, while China's economy has been growing and developing rapidly. The dynamics and structure of the economies of both countries determine the dynamics and structure of their import flows.

Imports of goods to Ukraine between 2014 and 2018 increased from 54 to 57 billion US dollars, or by $5 \%$. During the same period, imports of goods to China increased from 1959 to 2135 billion US dollars, or by $9 \%$. Imports of goods to China have generally been growing faster since 2000 , reflecting the faster development of the Chinese economy compared to Ukraine's.

The structure of imports is closely linked to the structure of the economy. China successfully modernized and diversified its economy during the 1990s and 2000s, while Ukraine's economy went going through processes of deindustrialization and narrowing of the range of export products. In 2014-2018, consumer goods dominated the structure of imports to Ukraine, with an average share of $42.1 \%$, and raw materials had the lowest share (11.9\% on average). By contrast, in China, capital goods and raw materials were responsible for the largest share of imports (40.1\% and $25.0 \%$, respectively), while consumer goods had the smallest share (13.1\%).

The Ukrainian economy is more dependent on imports than the Chinese economy. In 2014-2018, Ukraine's share of imports of goods and services in GDP was equal to $53.8 \%$, while for China, this figure was $18.7 \%$. The dependence of Ukraine's economy on imports does not show a decreasing trend. While in 2013 the share of imports in GDP was 51.1\%, in 2017, it increased to 55.7\%. The Ukrainian economy's dependence on imports has been high since 2000; it has fallen below 50\% only three times (in 2006, 2009, and 2010).

China became a full-fledged member of the WTO in December 2001, while Ukraine joined in May 2008. Between 2014 and 2018, China had higher levels of tariff and non-tariff protection of its domestic market than Ukraine (Table 1). The Effectively Applied Weighted Average Tariff in 2018 in China was 3.39\%, and 1.56\% in Ukraine. 
Table 1. Levels of tariff and non-tariff protection of Ukraine and China, 2014-2018

\begin{tabular}{|l|c|c|}
\hline \multicolumn{1}{|c|}{ Indicator } & Ukraine & China \\
\hline Simple Average Tariff, \% & 2.30 & 7.56 \\
\hline incl. Raw materials & 3.81 & 5.46 \\
\hline Capital goods & 1.06 & 5.27 \\
\hline Intermediate goods & 1.39 & 6.18 \\
\hline Consumer goods & 3.52 & 10.29 \\
\hline Maximum Rate, \% & 50 & 695 \\
\hline incl. Raw materials & 20 & 65 \\
\hline Capital goods & 20 & 45 \\
\hline Intermediate goods & 50 & 65 \\
\hline Consumer goods & 50 & 695 \\
\hline Duty-free Tariff Lines Share, \% & 62.39 & 25.84 \\
\hline No. of Non-Tariff Measures Affected Products (HS 6 Digit) (2013) & 23 & 81 \\
\hline
\end{tabular}

Source: World Integrated Trade Solution.

The trade policy in Ukraine and China is based on similar principles, targeted at providing the maximum support to the development of domestic production. In particular, imports of raw materials and capital goods are subjected to minimum tariffs, while imports of consumer goods are subjected to maximum tariffs. In particular, the Effectively Applied Weighted Average Tariff in 2018 for raw materials in Ukraine was $0.97 \%$ (1.21\% in China), for capital goods, it was 0.94 and 2.54 , respectively; for intermediate goods -1.07 and 3.17; for consumer goods -2.36 and 10.22 (World Integrated Trade Solution n.d.). The difference was that the maximum tariff rate (for consumer goods) in Ukraine was 2.5 times higher than the minimum tariff rate, and in China, it was 8.4 times higher.

The policy of import substitution in Ukraine was implemented with an emphasis on individual industries or through the development of complex programs. In the framework of import substitution policy, localization requirements were also applied to foreign direct investors. According to the Law of Ukraine "On the Development of the Automobile Industry of Ukraine” of March 18, 2004 № 1624-IV, which came into force on June 1,2004, import duty rates on cars imported to Ukraine were increased.

In September 2011, the Cabinet of Ministers of Ukraine approved the State Program for the Development of Domestic Production, developed for 2012-2018. The program provided for the use of non-tariff technical, sanitary, and phytosanitary measures, certification and standardization, licensing, and quotas to protect domestic producers. The construction of a plant to produce nuclear fuel for the purpose of import substitution of relevant products (with the use of foreign investments) in Smolin, in the Kirovohrad region, was one of the measures included in the program.

Chinese companies implemented import substitution measures both with and without the involvement of Western capital. At the time of Huawei's establishment (1987), China imported all telecommunications equipment. The company refused to enter into 
joint ventures with Western transnational corporations, relying on its own research facilities, while actively using reverse engineering, i.e., studying the design of equipment of Western transnational corporations. At the same time, the company received state support because its products were significant for national defense (Huawei n.d.). China's domestic car market demand is now almost entirely satisfied by domestic production, with imports accounting for 9-10\% of sales, although back in 1993-1994, the market was divided equally between imports and domestic production. Ninety percent of cars produced in China are provided by joint ventures with foreign manufacturers, such as Volkswagen, Toyota, Peugeot, Citroen, Honda, Renault, Nissan, and BMW (Industry of China n.d.).

In order to implement import substitution, China has actively used the requirements of localization of production. In 2005, China launched a program to manufacture wind turbines with the condition that at least $70 \%$ of components will be purchased using budget costs in China. This was later rejected due to protests from foreign suppliers, who pointed out that the document contradicted China's commitments to the WTO. However, by that time, the localization rate for local and foreign firms had already reached 70\% (Studwell 2017, pp. 316-317). As part of China's five-year development plan for 2016-2020, a "Made in China 2025" plan was developed to increase the share of local raw materials in production to $40 \%$ in 2020 and to $70 \%$ in 2025 (Made in China 2025 2015).

In 2014-2018, relatively large amounts of engines for aircraft and propellers produced by Ukrainian company Motor Sich were imported to China. For the purpose of import substitution, the Chinese side agreed with Motor Sich on joint production in Chongqing Municipality (China and Motor Sich... 2017), but in 2019, Skyrizon Aircraft and Xinwei Technology Group bought more than half of the shares from Motor Sich JSC. Today the agreement is being reviewed by the Antimonopoly Committee of Ukraine (Boguslaev confirmed the sale... 2019). This agreement is unfavorable for Ukraine, as there is a high probability that production (at least equal to the volume of Chinese imports) will be moved to a plant in China.

\section{Attracting China's investment to Ukrainian industry}

Awareness about the real difficulties of Ukraine's economic development, reflected in the slowdown in economic growth and the aging of fixed capital, puts on the agenda the problem of further developing Ukrainian industry in the framework of open markets. In this context, China's experience is important for Ukraine.

The creation of new industries and building industries that had significant export potential almost from scratch (automotive, electronics, etc.) was an important feature of China's industrial policy. The emphasis was on domestic production, not on production from imported components, screwdriver assembly, etc. The main purpose of attracting foreign investment was to obtain modern technologies. This industrial 
policy has enabled China to reach a new level of industrial development. In particular, in the already mentioned program "Made in China 2025", published in 2015, the Chinese government outlined the priorities of modernizing Chinese industry based on modern technologies. The main goal of China's comprehensive and ambitious industrial policy is to make the country a world manufacturing power and a high-tech superpower.

Unlike the Chinese Industry Modernization Program, which aims to transition to "smart" industry, the Ukrainian Industry Development Strategy is much more modest and aims to find ways to address key issues, including modernization and growth of industrial production; regional development of industry, and increase its resource efficiency.

Projects targeted at developing the production of goods with high value added, include space and aviation, machine-building products; energy-saving and vehicles using alternative energy sources; new materials; high-tech medical equipment, should become the priority areas for attracting Chinese investment to Ukrainian industry.

Attracting Chinese investment to the space industry is promising for both Ukraine and China, as Ukraine already has all the components of a space industry - science, technology, production, and human resources - to implement full-scale space projects. On the other hand, China is catching up with the United States in many areas, including the space sector. Recently, China announced a plan for a piloted moon landing and operating reusable rocket launchers. Although the industry is 15 years behind, China is looking to the future with confidence (China seeks leadership... 2018).

In the last decade, Ukrainian aircraft construction has not developed effectively, which has led to a loss of position in the world market. The breaking of the Ukrainian aviation industry's ties with Russia prompted Ukraine's aircraft companies to make profound structural changes and seek ways to attract investment in aircraft construction from other countries, including Europe and East and Southeast Asia. In this context, Ukraine's participation in the OBOR initiative looks promising. For Ukraine, this is, first of all, an opportunity to attract additional investment resources to the aviation industry and enter the markets of East and South-East Asia. In addition, China is interested in expanding investment activities in Ukrainian aircraft production. ${ }^{1}$ In particular, China is showing interest in joint production of aircraft engines with the State Concern Ukroboronprom.

The machinery construction industry of Ukraine incorporates more than 20 specialized branches, i.e., practically all categories of mechanical engineering. To increase the efficiency of the enterprises of Ukraine's machinery construction industry within the framework of the OBOR initiative, there is an opportunity to attract Chinese investors, especially to the field of industrial machinery construction. In this case, joint production of the two countries would be a better option. Ukraine, which is going

1 China is studying the possibilities of mass producing a new Ukrainian transport plane, the An-178, with a capacity of up to 18 tons developed by the Antonov State Enterprise (Kyiv) at facilities in China. 
through the process of industrialization, could not skip the development of domestic modern engineering. At the same time, Ukrainian enterprises have a rich raw material base for their development, starting with ore and ending with super hard materials. Attracting investment from China will promote the development of innovative and management technologies.

As part of attracting Chinese investment to the production of energy-saving and alternative energy vehicles, Ukraine should focus on China's state and private companies to use their experience inside their home country. These can be companies such as Jinko Solar, JA Solar, Trina, Longi, Canadian Solar, Hanwha Q Cells, Risen, Suntech, Astronergy, Telesun (ITC).

Ukraine will benefit from attracting Chinese investors to the energy-saving and alternative energy vehicle production sectors in the form of creating new jobs, revenues to state and local budgets, building new energy-efficient industries and related infrastructure across the country, and ultimately positive environmental consequences. For Chinese investors, creating or relocating the production of energy-saving and alternative energy vehicles to Ukraine will allow it to expand the market not only in Ukraine but also in the EU.

Developing and implementing new materials is necessary primarily for the development of mechanical engineering, aerospace, equipment and energy industries, medicine, and more. Therefore, attracting Chinese investment in these areas, in our opinion, will have positive results. However, new prospects will open for Ukraine in the field of producing new materials when it starts to develop modern academic and applied science.

While considering attracting Chinese investment in the production of high-tech medical equipment, it should be noted that China has long been known for its in-depth knowledge of the human body and traditional medicine. Their developments are aimed at finding a cure for a variety of diseases, creating specialized apparatus to detect and classify diseases, and creating flexible batteries that run on saline liquids, including sweat or tears.

In our opinion, the innovative potential of Ukraine in producing high-tech medical devices is still estimated to be at a high level, especially if we consider important parameters such as generating new ideas and technologies. Many Ukrainian specialists already work in world research centers. To remain an innovative state, Ukraine needs to develop strong cooperation with China.

However, in attracting Chinese investment in these promising areas of industry, Ukraine must still consider the experience of other countries; and this experience is not always positive. For example, Belarus, having signed an official protocol with the Ministry of Commerce of China in 2014, expected Chinese investors to build new high-tech enterprises. In order to implement the measures provided by the protocol, an industrial park "Big Stone" (80 sq. km), was created with a Chinese corporation's investment of more than 1 billion US dollars over several years, with the total investment sum expected to be 5.5 billion US dollars. Plants and housing were built with 
these funds, but the main object of the industrial park was a large logistics center, not high-tech enterprises (Lavnykevych 2018).

In conclusion, it should be noted that attracting Chinese investment to Ukraine could have both benefits (from significant investments) and threats (from targeted changes in investment by investors). Therefore, in deepening bilateral cooperation, Ukraine must clearly understand what priority tasks it can solve at the expense of Chinese investment and what goals a Chinese investor is pursuing in Ukraine.

\section{Cooperation in the field of innovation}

The economic development of the country depends on the development of industrial enterprises based on innovations. The effectiveness of the activity is estimated by the innovation indicator, according to which China ranked $14^{\text {th }}$ among 129 countries, while Ukraine was in $47^{\text {th }}$ place (Global innovation index 2019). According to Business dynamism, China took $36^{\text {th }}$ place (Ukraine $\left.-85^{\text {th }}\right)$, and according to Innovation capability $-24^{\text {th }}$ place (Ukraine $-60^{\text {th }}$ ) among 141 countries (The Global Competitiveness Report 2019).

China's industrial enterprises produce more than $34 \%$ of the world's innovative products, and the Chinese government creates special institutional conditions for their development. This applies not only to the existing legal framework in the field of innovation of enterprises, but also to the development priorities of industries identified in government programs ("Spark", “Torch", "Plan 2020", "Program 863", “Made in China - 2025" and others.

After analyzing state regulations and support for innovation development of industrial enterprises capable of producing competitive products, China's long-term priorities should be understood as supporting the formation of high-tech industries, including the creation of an efficient technology transfer system; providing state support in the creation and development of special forms of organization of innovation (FEZs, clusters, industrial parks, technology parks, etc.) in the provinces of the country that have a network of scientific, technical and industrial enterprises with high scientific and technological potential; using existing scientific and technical potential for the development of priority economic activities (agricultural technologies, biotechnology, nuclear and space technologies, etc.); creating favorable conditions for conducting research in the field of scientific and technical development (chemical technologies and new materials, information technologies, etc.); improving the regulatory framework in the field of development of scientific and innovation activities; integration into the global innovation sphere.

In contrast to China, the Ukrainian processing industry in recent years has been characterized by a decrease in the share of GDP from $20.0 \%$ in 2007 to $12.4 \%$ in 2017. There has also been a decrease in the number of domestic enterprises in the processing industry to 759 units, of which 680 units are innovation enterprises (production 
of food, beverages, and tobacco products; metallurgical production, production of finished metal products, except for the manufacturing of machinery and equipment; the manufacture of machinery and equipment not included in other groups ${ }^{2}$ ).

Financing the innovation activities of the processing industries was mainly carried out at the expense of own funding $(83.5 \%$ of the total financing of innovative activity of processing industry of Ukraine). The main reasons for the decline in production include the conflict with the Russian Federation, the loss of industrial potential in eastern Ukraine, and the loss of markets in the post-Soviet space, which were not compensated for by the signing of the Deep and Comprehensive FTA between Ukraine and the EU (2016).

The problem lies in the lack of funding for state programs in the field of innovation. Based on the Chinese experience, the intensification of innovation in Ukraine is possible by creating and developing organizational forms of innovation, among which the most common are FEZs (Shenzhen, Zhuhai, Shantou, Xiamen, Hainan). Clusters are another form of innovation activity of enterprises. Their functioning is supported by the national cluster development program and cluster strategy. Thanks to state support, 150 clusters have been created in China, while in Ukraine, only 50 were created. Ukraine has developed several draft regulation documents on the functioning of clusters, although they remain unapproved.

Industrial parks are one of the most effective organizational forms of innovation activity of industrial enterprises (54 units in China, 43 in Ukraine). In China, industrial parks form about $10.0 \%$ of GDP, accumulate $30.0 \%$ of foreign direct investment, generate $37 \%$ of the country's commodity exports, and employ approximately four million people. Transnational industrial parks generate particular interest, among them, the China-Singapore Suzhou Industrial Park (with an area of $260 \mathrm{~km}^{2}, 330$ companies, 35,000 employees, and 100 billion US dollars investment), and the Great Stone China-Belarus industrial park (with an area of $112.5 \mathrm{~km}^{2}$ ). A favorable investment climate has been created for their functioning, and this climate is guaranteed both by national legislation and by special international agreements and obligations (Egorov, Boiko, and Griga 2015; Boiko 2017, pp. 112-132).

China supports the operation of technology parks in conjunction with Ukrainian enterprises. In particular, in 2011, the Ukrainian-Chinese Techno Park was established in Shanghai (cooperation in the field of marine sciences and technologies, biomedicine, aerospace, major energy sources, etc.) (Opening ceremony... 2011), and in 2016, the Chinese-Ukrainian Center for Scientific and Technical Cooperation in Harbin (a platform for scientific cooperation in certain areas, including electric welding).

Ukraine also has a network of 19 technology parks. However, in 2005, some of the most important articles of the laws regulating the activities of technology parks were repealed. Subsequently, the preferences of technology parks in the field of taxation and

2 Information for 2014-2017 is given without taking into account the temporarily occupied territory of the Autonomous Republic of Crimea, the city of Sevastopol and part of the temporarily occupied territories in Donetsk and Luhansk regions. 
operating activities were partially restored. To intensify Ukrainian-Chinese cooperation in the field of innovation, it is necessary to create a favorable investment climate to attract Chinese and domestic investors to develop joint industrial enterprises on an innovative basis in priority economic activities.

\section{Conclusions}

Based on the results of the analysis in accordance with our four detailed research tasks, a few conclusions can be formulated.

1. A comparative analysis of the trade policy of Ukraine and China and trends in bilateral trade in goods showed that the most likely scenario for mutual trade development would be strengthening the raw material orientation of Ukrainian exports with an emphasis on agricultural goods and the increase in dependence of Ukraine's domestic market on Chinese goods. This scenario works to provide the main benefits that China plans to gain from the implementation of the OBOR initiative, namely, providing raw materials for its own processing industries, providing food for its own population, and promoting Chinese goods to markets around the world.

2. The dependence of Ukraine's economy on imports remains high without any significant signs of decline. This is an unnatural phenomenon given the large population, large territory, and significant production potential. The high level of import dependence resulted from the long-term economic crisis of the 1990s, the policy of trade liberalization, and a number of other factors. The analysis verified our hypothesis that given the high risks of deterioration of Ukraine's trade balance due to trade liberalization with China, the conclusion of an FTA with China at the current stage of Ukraine's development is not appropriate.

3. At this stage of Ukraine's development, it is recommended to limit the potential partnership to concluding a Bilateral Investment Agreement with China, which China should conclude before starting negotiations on the establishment of the FTA. Ukraine's economy needs to intensify domestic production by attracting foreign direct investment and mobilize domestic sources of growth. China successfully followed this path during the 1990s and 2000s, and its experience is important for Ukraine. In the context of this experience, it is rational to deploy innovation and investment cooperation between Ukraine and China, mainly in Ukraine, taking into account its territorial proximity to the EU, developed transport infrastructure, and high transit potential, which is also useful for China in the OBOR initiative. The main areas of attracting Chinese investment in Ukrainian industry are high-tech areas such as aviation, the shipbuilding industry, and the development of new materials.

4. Considering the state of innovative development of industrial enterprises of Ukraine, it is expedient to create clusters in Ukraine with the involvement of Chinese investments within the framework of the OBOR initiative. In addi- 
tion, the analysis of China's successful experience in the development of other special forms of organizing innovation proves the importance of developing technology parks, industrial parks, and FEZs. To implement this, it is necessary to make changes in the institutional support for the development of innovation in Ukraine.

\section{References}

AEGIS EUROPE (2016), 10 Commitments China made when it joined the WTO and has not respected, http://staticl.squarespace.com/static/5537b2fbe4b0e49ale30c01c /t/568f7bc51c1210296715af19/1452243910341/The+10+WTO+Committments+of+ China.pdf (accessed: 28.02.2020).

Bieliński, T., Markiewicz, M., Oziewicz, E. (2019), Do Central and Eastern Europe Countries Play a Role in the Belt and Road Initiative? The Case of Chinese OFDI into the CEE-16 Countries, "Comparative Economic Research. Central and Eastern Europe", 22 (2), pp. 7-22, https://doi.org/10.2478/cer-2019-0009

Boguslaev confirmed the sale of the Chinese company "Motor Sich" (2019) (in Russian), https://www.epravda.com.ua/rus/news/2019/12/13/654876/ (accessed: 5.02.2020).

Boiko, O.M. (2017), Structural components of the innovation environment of the national economy: Ukraine and other countries of the world, Materials of reports of the international scientific-practical conference "Socio-economic development of organizations and regions of Belarus: efficiency and innovation", dedicated to the year of science, EE "VSTU”, Vitebsk.

China and Motor Sich are building a plant (2017) (in Russian), https://www.ukrinfo rm.ua/rubric-other_news/2242211-kitaj-i-motor-sic-buduut-zavod.html (accessed: 5.02.2020).

China seeks leadership in the space industry (2018) (in Russian), https://blog.allo.ua/kita j-stremitsya-k-liderstvu-v-kosmicheskoj-otrasli_2018-01-36/ (accessed: 5.02.2020).

Choroś-Mrozowska, D. (2019), The Chinese Belt and Road Initiative from the Polish Perspective, "Comparative Economic Research. Central and Eastern Europe", 22 (2), pp. 39-53, https://doi.org/10.2478/cer-2019-0011

Egorov, I.Y., Boiko, O.M., Griga, V.Y. (2015), Industrial parks in Ukraine: problems of formation and prospects of development, National Academy of Sciences of Ukraine, Institute of Economics and Forecasting of the National Academy of Sciences of Ukraine, Ministry of Economic Development and Trade of Ukraine, Research Economic Institute, Kyiv.

Ezell, S.J., Atkinson, R.D. (2015), False Promises: The Yawning Gap Between China's WTO Commitments and Practices, The Information Technology \& Innovation Foundation, September 2015, http://www2.itif.org/2015-false-promises-china .pdf?_ga=2.196300396.1589681642.1551882052-593599331.1551882052 (accessed: 28.02.2020).

Global innovation index 2019, Creating Healthy Lives, The Future of Medical Innovation (in Russian), https://www.wipo.int/publications/ru/details.jsp?id=4434 (accessed: 5.02.2020). 
Huawei, https://en.wikipedia.org/wiki/Huawei (accessed: 6.04.2020).

Industry of China (in Russian), https://ru.wikipedia.org/wiki/\%D0\%9F\%D1\%80\%D0 \%BE\%D0\%BC\%D1\%8B\%D1\%88\%D0\%BB\%D0\%B5\%D0\%BD\%D0\%BD\%D0\%BE \%D1\%81\%D1\%82\%D1\%8C_\%D0\%9A\%D0\%9D\%D0\%A0 (accessed: 2.02.2021).

ITC, TOP 10 manufacturers of solar modules in 2019, (in Russian), https://itc.ua/news /desyatka-krupnejshih-proizvoditelej-solnechnyh-modulej-v-2019-godu/ (accessed: 5.02.2020).

Lavnykevych, D. (2018), Be Afraid of Chinese Who Bring Gifts, “Zerkalo Nedeli”, 36 (in Russian), https://zn.ua/finances/boysya-kitaycev-dary-prinosyaschih-293207 _.html (accessed: 5.02.2020).

Lingling, H. (2013), On re-invigorating the Australia-China Free Trade Agreement negotiation process, "Journal of World Investment and Trade", 14 (4), pp. 672-696, https://doi.org/10.1163/22119000-01404004

Made in China 2025 (2015), https://www.csis.org/analysis/made-china-2025 (accessed: 6.04.2020).

MOFCOM (2004), Foreign Trade Law of The People's Republic of China, http://english .mofcom.gov.cn/aarticle/policyrelease/internationalpolicy/200705/200705047158 45.html (accessed: 28.02.2020).

MOFCOM (2008), Free Trade Agreement between the Government of the People's Republic of China and the Government of New Zealand, http://images.mofcom.gov.cn /gjs/accessory/200804/1208158780064.pdf (accessed: 28.02.2020).

MOFCOM (2015), Free Trade Agreement between the Government of Australia and the Government of the People's Republic of China, http://fta.mofcom.gov.cn/Australia /annex/xdzw_en.pdf (accessed: 28.02.2020).

Opening ceremony of the Chinese part of the Ukrainian-Chinese Technopark in Shanghai (2011) (in Russian), https://china.mfa.gov.ua/news/2660-vidbulasy-urochista-c eremonija-vidkrittya-kitajsykoji-chastini-ukrajinsyko-kitajsykogo-tehnoparku-v-s hankhaji (accessed: 2.02.2021).

Ostashko, T., Olefir, V. (2019), Prospects offree trade with China: development of domestic export and risks of import dependence, "Economy and Forecasting", 1, pp. 124152, https://doi.org/10.15407/econforecast2019.01.124

Studwell, D. (2017), Why Asia Succeeded. Successes and failures of the most dynamic region of the world, Nash Format, Kyiv.

The Global Competitiveness Report 2019, http://www3.weforum.org/docs/WEF_TheG lobalCompetitivenessReport2019.pdf (accessed: 5.02.2020).

UN Comtrade Data Base, https://comtrade.un.org/ (accessed: 5.02.2020).

World Integrated Trade Solution, https://wits.worldbank.org/Default.aspx?lan $\mathrm{g}=\mathrm{en}$ (accessed: 5.02.2020).

WTO (2001a), Protocol on the Accession of the People's Republic of China, The Ministerial Conference Decision of 10 Nov. 2001, https://www.wto.org/english/thewto _e/acc_e/completeacc_e.htm\#chn (accessed: 28.02.2020).

WTO (2001b), Report of the Working Party on the Accession of China, https://www .wto.org/english/thewto_e/acc_e/completeacc_e.htm\#chn (accessed: 28.02.2020). 
WTO (2018a), China donates USD 1 million to support implementation of Trade Facilitation Agreement, "WTO News 2018", 2 Feb. 2018, https://www.wto.org/english /news_e/pres18_e/pr816_e.htm (accessed: 28.02.2020).

WTO (2018b), China. Trade Policy Review, Revision, 14 Sep.2018,WT/TPR/G/375, Trade Policy Review Body, https://www.wto.org/english/tratop_e/tpr_e/tp_rep_e.htm\#by country (accessed: 28.02.2020).

WTO (2018c), China. Trade Policy Review, 6 June 2018, Trade Policy Review Body, Report by China, https://www.wto.org/english/tratop_e/tpr_e/g375_e.pdf (accessed: 28.02.2020).

\section{Analiza porównawcza polityki handlowej i przemysłowej Ukrainy i Chin w kontekście inicjatywy OBOR}

Gospodarka światowa ewoluuje w kierunku wielobiegunowej globalizacji, a Chiny stały się nowym biegunem rozwoju gospodarczego. Ukraina, podobnie jak inne kraje, szuka sposobów współpracy z Chinami w zakresie handlu i inwestycji. Z kolei Chiny oferują model współpracy w ramach inicjatywy OBOR. Ponieważ oprócz chińskich inwestycji w infrastrukturę transportowo-logistyczną OBOR ma na celu zawarcie umów o wolnym handlu z krajami uczestniczącymi w inicjatywie, artykuł skupia się na zagadnieniach polityki handlowej, przemysłowej i innowacyjnej Ukrainy w kontekście inicjatywy OBOR. Warunki handlu między Ukrainą a Chinami nie są symetryczne ze względu na różnice w wielkości gospodarek i handlu. Warunki handlu na Ukrainie są również dość liberalne, podczas gdy rynek chiński jest chroniony przez wyższe bariery o charakterze taryfowym i pozataryfowym. Obecna sytuacja we wzajemnym handlu ma również charakter asymetryczny. Ukraina eksportuje do Chin głównie surowce, podczas gdy eksport z Chin na Ukrainę jest zdominowany przez dobra inwestycyjne i konsumpcyjne.

Zależność ukraińskiej gospodarki od importu jest duża, bez zauważalnych oznak spadku. W latach 2014-2018 udział importu towarów i usług w PKB na Ukrainie wynosił średnio 54\% (dla porównania w Chinach - 19\%). 55\% ujemnego salda handlu Ukrainy towarami w 2018 roku było wynikiem wymiany handlowej z Chinami. Chiny dążą do zawarcia umów o wolnym handlu w ramach inicjatywy OBOR, ale w obecnej sytuacji liberalizacja handlu z Chinami spowoduje wzrost ukraińskiego eksportu surowców do Chin i zwiększy zależność od chińskiego importu. Z drugiej strony możliwości inwestycyjne, produkcyjne oraz naukowe i technologiczne Chin mogą stać się znaczącym czynnikiem służącym modernizacji gospodarczej Ukrainy. Gałęzie przemysłu wysokich technologii, takie jak lotnictwo, przemysł stoczniowy, bioinżynieria, rozwój nowych materiałów itp., są obiecującymi obszarami przyciągającymi chińskie inwestycje. Interesujące dla Ukrainy są chińskie doświadczenia w realizacji szeregu programów państwowych w zakresie rozwoju innowacji w chińskich przedsiębiorstwach przemysłowych. Wskazane jest wprowadzenie systemu wspierania klastrów, parków przemysłowych, Wolnych Stref Ekonomicznych (WSE) i parków technologicznych do ukraińskiego ustawodawstwa dotyczącego systemu innowacji na Ukrainie.

Słowa kluczowe: Inicjatywa OBOR, Chiny, Ukraina, polityka handlowa, umowy o wolnym handlu, polityka przemysłowa, polityka innowacyjna 